Düzakın, H., \& Yılmaz, S. (2021). The Determinants of The Level of Financial Literacy in Turkey. Copernican Journal of Finance \& Accounting, 10(1), 9-30. http://dx.doi.org/10.12775/ CJFA.2021.001

\author{
Hatice Düzakin* \\ Çukurova University \\ SÜREYYA YILMAZ ${ }^{* *}$ \\ Çağ University
}

\title{
THE DETERMINANTS OF THE LEVEL OF FINANCIAL LITERACY IN TURKEY
}

Keywords: financial literacy, financial behaviour, financial knowledge, financial attitudes.

\section{J E L Classification: G53.}

\begin{abstract}
The main objective of this study was to explain individuals' financial literacy levels through socioeconomic and demographic variables. A random sample of 1000 participants was recruited from Turkey. As an indicator of the financial literacy level, a measure with three constructs was adopted: financial attitude, financial behaviour and financial knowledge. Logit model was estimated from these explanatory variables: gender, age, marital status, number of family members, education, income, number of persons with income, household income and working conditions. In the logit model results, the effect of gender, age and education was statistically significant and positive. The results emphasized that there is a relationship between financial literacy level and
\end{abstract}

Date of submission: February 18, 2021; date of acceptance: May 1, 2021.

* Contact information: hduzakin@cu.edu.tr, Çukurova University, Faculty of Economics and Administrative Sciences, Adana, Turkey, phone: +90 3223386084; ORCID ID: https://orcid.org/0000-0002-8840-1815.

** Contact information (corresponding author): sureyyayilmaz@cag.edu.tr, Çă University, Faculty of Economics and Administrative Sciences, Mersin, Turkey, phone: +90 3246514800; ORCID ID: https://orcid.org/0000-0003-4150-4101. 
gender, age and education. Additionally, the results of this study indicated that the level of financial literacy is $52.9 \%$ in Turkey.

\section{IIIIRTODUCTION}

Capital markets are seen as one of the crucial financing options in the economic growth of countries. For this purpose, development of supply and demand in capital markets has become one of the top priority issues in terms of countries. Development of supply and demand in the market depends on increasing savings and using the options of the individuals who make savings effectively. In addition to financing individuals' incomes correctly, being able to direct them to the right investments and savings is defined as "financial literacy". Financial literacy is expressed in its most general form as, "The skill, motivation and confidence of having knowledge and an understanding on financial concepts and risks, making effective decisions with these knowledges and understanding in different financial contexts, developing the financial well being of the society and using it to facilitate participation in economic life." (OECD, 2013). As a result of the increasing significance of financial literacy, studies have started to determine the level of financial literacy in developing and developed countries. As a result of studies, it has been determined that levels of financial literacy are low around the world (Chen \& Volpe, 1998; Furtuna, 2007; Çam \& Barut, 2015), the potential cost of low financial literacy levels have been revealed worldwide with financial crises, and this had led countries to develop financial education strategies. For the purpose of increasing the level of financial prosperity, institutions and organisations continue their work including the "International Gateway for Financial Education", financial education programmes and Jumpstart by the Organisation for Economic Cooperation and Development (OECD), financial literacy programmes organised by the World Bank and the Programme for International Student Assessment (PISA), financial literacy programmes by the Financial Literacy Association (FODER) in Turkey and initiatives by the National Endowment for Financial Education (NEFE) in the United States. The main reason for this is that individuals' management of their financial lives is as important as managing the national economy. The motivation of this study was to determine the relationship between financial literacy and savings that contribute to countries' economies in the long term and how they are evaluated by individuals. In this study, therefore, it was aimed to determine the level of financial literacy in Turkey. Along with this, avoiding unnecessary 
expenses and transitioning from a consumer society to a knowledge, economy and technology society will increase the financial literacy levels of countries. As a matter of fact, in developed countries such as the United States and the United Kingdom, it is observed that they create savings funds, have retirement plans, and it is easy to access and use knowledge in their financial markets (Danes \& Hira, 1987; Volpe, Chen \& Pavlicko, 1996).

\section{LITERATURE REVIEW}

\section{Financial Literacy}

The concept of financial literacy has the same content, but it is expressed in different terms in some countries. For example, "Financial Literacy" is used in the USA, Australia and New Zealand, while Canada and the United Kingdom use it as "Financial Capability" (Orton, 2007). Along with these, the terms "Financial Education and Financial Awareness" are those that are the closest to financial literacy (Gökmen, 2012). The definition of the concept of financial literacy is expressed in different definitions in the financial literature. The definitions of financial literacy from 1996 to today are as follows.

According to Schagen and Lines (1996), financial literacy is the ability to make efficient and right decisions with financial management (use of money), whereas, according to Chen and Volpe (1998), financial literacy is the most effective concept in making financial decisions in an uncertain environment.

The concept of financial literacy in the 2000s was defined as being aware of the financial concept of an individual, obtaining information needed in decision-making, and understanding and assessment of the information (Mason \& Wilson, 2000).

The Organisation for Economic Co-operation and Development (OECD) (2005) described financial literacy as not only financial knowledge but also to include financial attitudes, behaviour and talent.

While Taşçı (2011) defined financial literacy as being aware of financial risks and opportunities, making informed financial decisions and making choices, Karabacak (2013) stated that financial literacy in its simplest form is the state of using financial resources effectively with this kind of information by having knowledge on simple economic and financial issues. 
Furthermore, according to Financial Literacy Association of Turkey (FODER), which was established to determine the financial literacy level in Turkey and achieve development on this issue, financial literacy is the capability of the individual to make an informed assessment regarding the use and management of money and to make effective decisions, or in other words, it is the state of individuals of having gained the capability and skills of utilizing their income, savings and investments wisely and forming budgets correctly.

Considering all definitions, the general statement that arises expresses the following: financial literacy refers to individuals' effective use and utilization of money management. It should not be thought that individuals have to be an expert or a professional in the field of finance to be considered financially literate. Financially literate individuals are those who have financial knowledge on a level sufficient for themselves and their families and financial habits such as saving. It is sufficient for financially literate individuals to know the difference between shares and bills of exchange, but they are not expected to know how to use both. Different components are used while assessing the financial literacy levels of individuals.

In a study conducted by Atkinson and Messy (2012) with the support of OECD, a broader definition was made for financial literacy, and financial literacy was measured as a composition constituted by the consciousness, knowledge, talent, attitudes and behaviours necessary for being able to make financial decisions and ultimately reach financial prosperity. It was proposed that the components of financial literacy are financial knowledge, financial attitudes and financial behaviours. In this study, the financial knowledge, behaviour and attitude components were used to determine the level of financial literacy.

\section{Previous Studies on Financial Literacy}

Financial literacy is considered as one of the fields of literacy required by the digital age. In today's world where rapid transformations, innovations and a large data flow are experienced, while financial literacy has become a globally significant phenomenon, it is also one of the most important topics in the finance literature which has been most research and discussed and on which various studies have been conducted. In this part of the study, information on some studies on the topic of financial literacy may be seen in table 1 . 
Table 1. Financial Literacy Literature

\begin{tabular}{|c|c|c|c|}
\hline Author(s) & Year & Method & Results \\
\hline Chen and Volpe & 1998 & $\begin{array}{l}\text { University/ } \\
\text { Survey }\end{array}$ & $\begin{array}{l}\text { Financial literacy levels of women, people with } \\
\text { less education and those under } 30 \text { years of age } \\
\text { are people's financial literacy level is low. }\end{array}$ \\
\hline $\begin{array}{l}\text { Cude, Lawrence, Lyons, } \\
\text { Metzger, LeJeune, } \\
\text { Marks and Machtmeset }\end{array}$ & 2006 & University/online survey & $\begin{array}{l}\text { Individuals' financial decisions are affected by } \\
\text { family. }\end{array}$ \\
\hline Kieschnick & 2006 & High school / survey & $\begin{array}{l}\text { Self-confidence and financial literacy level have } \\
\text { a positive relationship. }\end{array}$ \\
\hline Worthington & 2006 & $\begin{array}{l}\text { Austrian Households/ } \\
\text { telephone survey }\end{array}$ & $\begin{array}{l}\text { Financial literacy levels of people at ages of } 50 \text { - } \\
60 \text {, workers, farmers and those graduated from } \\
\text { university are high. }\end{array}$ \\
\hline Furtuna & 2007 & University / survey & $\begin{array}{l}\text { Financial literacy level of the unemployed and } \\
\text { women are low. }\end{array}$ \\
\hline OECD & 2009 & 18-countries/ university & $\begin{array}{l}\text { The level of financial literacy is different for } \\
\text { each country. }\end{array}$ \\
\hline $\begin{array}{l}\text { Lusardi, Mitchell and } \\
\text { Curto }\end{array}$ & 2010 & University / survey & $\begin{array}{l}\text { The family situation (rich or poor) affects level } \\
\text { of financial literacy. }\end{array}$ \\
\hline Ansong and Gyensare & 2012 & University / survey & $\begin{array}{l}\text { Family's education level affects students posi- } \\
\text { tively. }\end{array}$ \\
\hline Atkinson and Messy & 2012 & 14 countries /survey & $\begin{array}{l}\text { Most people have financial knowledge but their } \\
\text { knowledge and interest level is different for } \\
\text { each country. }\end{array}$ \\
\hline Ergün, Şahin and Ergin & 2014 & Public university / survey & $\begin{array}{l}\text { There is mainly a relationship between financial } \\
\text { literacy and demographic characteristics. }\end{array}$ \\
\hline $\begin{array}{l}\text { Er, Temizel, Özdemir and } \\
\text { Sönmez }\end{array}$ & 2014 & $\begin{array}{l}5 \text { public universities / } \\
\text { survey }\end{array}$ & $\begin{array}{l}32 \% \text { have high, } 30 \% \text { have medium, } 16 \% \text { have low } \\
\text { financial literacy levels. }\end{array}$ \\
\hline Bayram & 2014 & Public University /survey & $\begin{array}{l}\text { Financial literacy levels of students taking } \\
\text { finance and accounting course are higher than } \\
\text { students of other departments. }\end{array}$ \\
\hline Potrich et al. & 2015 & Households /survey & $\begin{array}{l}67.1 \% \text { were classified as having a low financial } \\
\text { literacy level. }\end{array}$ \\
\hline Çam and Barut & 2015 & Public University /survey & Financial literacy level is so low. \\
\hline Alkaya and Yağlı & 2015 & Public university/ survey & $\begin{array}{l}\text { There is a significant relationship between } \\
\text { financial behaviour and financial attitudes. }\end{array}$ \\
\hline Çelikkol and Çelikkol & 2015 & Public university/ survey & $\begin{array}{l}\text { Financial literacy level of girls is higher compa- } \\
\text { red to boys. }\end{array}$ \\
\hline Dilek, Küçük and Eleren & 2016 & Public university / survey & $\begin{array}{l}\text { In department comparisons, economics stu- } \\
\text { dents have higher financial literacy levels than } \\
\text { others. }\end{array}$ \\
\hline
\end{tabular}


Table 1. Financial...

\begin{tabular}{|l|l|l|l|}
\hline \multicolumn{1}{|c|}{ Author(s) } & Year & \multicolumn{1}{|c|}{ Method } & \multicolumn{1}{c|}{ Results } \\
\hline \hline $\begin{array}{l}\text { Danışman, Sezer and } \\
\text { Gümüş }\end{array}$ & 2016 & $\begin{array}{l}\text { Turkish students (390)/ } \\
\text { survey }\end{array}$ & Financial literacy level is basic. \\
\hline FODER & 2017 & Survey/Households & Financial literacy level is 70\%. \\
\hline $\begin{array}{l}\text { Çam, Ayaydın, Çam and } \\
\text { Akdeniz }\end{array}$ & 2018 & TR90 Households/survey & $\begin{array}{l}\text { Income and education levels have a positive } \\
\text { relationship with financial literacy levels. }\end{array}$ \\
\hline Boz & 2019 & $\begin{array}{l}\text { Student's Family member/ } \\
\text { survey }\end{array}$ & $\begin{array}{l}\text { Students' family members have high levels of } \\
\text { financial literacy. }\end{array}$ \\
\hline Bağcı and Arabacı & 2019 & Public University/survey & $\begin{array}{l}\text { Students have a low financial literacy level due } \\
\text { to lack of calculating abilities. }\end{array}$ \\
\hline \hline
\end{tabular}

S o u r c e : compiled by the author.

Considering the studies that have been conducted, the topic of financial literacy is a topic that has newly become popular in Turkey. Studies in Turkey have usually focused on determining the financial literacy levels of university students and academic personnel and whether or not they have a relationship with demographic characteristics. Looking at the international literature, it is seen that studies may be traced back to older dates, while this concept has been studies since the 20th century. While similar studies are seen in the literature in Turkish, it was determined that, in the international literature, studies have also been conducted on topics such as determining the financial literacy levels of high school students and retired individuals. In this part of the study, a broad literature review was carried out, and what kind of improvement can be made on the topic was focused on.

\section{Research Methodology ANd Research Process}

\section{Data}

In this study, which was carried out to determine the financial literacy levels in Turkey, a questionnaire was applied on randomly selected households living in 12 provinces located in the LEVEL 1 region determined by the Turkish Statistical Institute (TÜIK). 
The questionnaire application included 1000 individuals, and the questions were directed to the participants via telephone and face-to-face interviews. The questionnaire implementation process started in March 2018 and ended in July 2018. The questions in the questionnaire that was used in the study were compiled from those used in the studies by van Rooij, Lusardi and Alessie (2011) and Potrich, Vieira and Kirch (2015). The questionnaire consisted of four parts. Questions on determining financial knowledge (8 questions), financial behaviour ( 27 statements) and financial attitude (10 statements) and current financial knowledge ( 8 questions) were asked of the participants. The questions on financial knowledge and current financial knowledge were multiple-choice questions with three options each, while the statements on financial behaviour and attitude were 5-point Likert-type (absolutely disagree, disagree, undecided, agree, absolutely agree) statements. The eight questions that were asked to determine the financial knowledge of the individuals responding to the questionnaire were questions on topics such as simple mathematical operation, time value of money, inflation, interest calculation and risk and diversification. The questions on current financial knowledge were those that measured topics such as blockchain and exchange rates. At the next stage of the study, the relationship between financial literacy and sociodemographic characteristics was aimed to be determined.

\section{METHODOLOGY}

\section{Econometric Model}

In this study that aimed to determine the financial literacy levels in Turkey, Logit regression analysis was carried out to reveal the relationship between the independent and dependent variables. In this study, the Stata MP 14 (64 bit) was used for analysis. Nonparametric scale and ordinal variables were described with frequency analysis, whereas scale parameters were described with means and standard deviations. Crosstabulation and Chi-Square analysis were used for contingency tables. Spearman's rho correlation was used for correlation matrix for study parameters. Logit model with margin effects were used for analysis for research question. The main equation was given as in the follows: 
Financial Literacy

$=\beta_{0}+\beta_{1}$ Gender $+\beta_{2}$ Age $+\beta_{3}$ Marital status

$+\beta_{4}$ Number of family members $+\beta_{5}$ Education $+\beta_{6}$ Income

$+\beta_{7}$ Number of income person $+\beta_{8}$ House income $+\beta_{9}$ Worker

\section{Research Hypotheses}

When financial literacy was considered within a theoretical framework and in the light of the literature review that was carried out, the following hypotheses were formed.

- $\mathrm{H}_{1}$ : Gender has a statistically significant predictive effect on level of financial literacy.

- $\mathrm{H}_{2}$ : Age has a statistically significant predictive effect on level of financial literacy.

- $\mathrm{H}_{3}$ : Marital status has a statistically significant predictive effect on level of financial literacy.

- $\mathrm{H}_{4}$ : Number of family members has a statistically significant predictive effect on level of financial literacy.

- $\mathrm{H}_{5}$ : Education has a statistically significant predictive effect on level of financial literacy.

- $\mathrm{H}_{6}$ : Income has a statistically significant predictive effect on level of financial literacy.

- $\mathrm{H}_{7}$ : Number persons with income has a statistically significant predictive effect on level of financial literacy.

- $\mathrm{H}_{8}$ : Household income has a statistically significant predictive effect on level of financial literacy.

- $\mathrm{H}_{9}$ : Working condition has a statistically significant predictive effect on level of financial literacy.

\section{Empirical Results and Discussion}

The demographic characteristics of the participants are presented in the table 2 . 
11. THE DETERMINANTS OF THE LEVEL OF FINANCIAL LITERACY IN TURKEY

Table 2. Demographic characteristics

\begin{tabular}{|c|c|c|}
\hline & Frequency (n) & Percent (\%) \\
\hline \multicolumn{3}{|l|}{ Gender } \\
\hline Female & 306 & 30.6 \\
\hline Male & 694 & 69.4 \\
\hline \multicolumn{3}{|l|}{ Age } \\
\hline $18-24$ & 33 & 3.3 \\
\hline $25-34$ & 243 & 24.3 \\
\hline $35-44$ & 335 & 33.5 \\
\hline $45-54$ & 247 & 24.7 \\
\hline $55-64$ & 101 & 10.1 \\
\hline $65+$ & 41 & 4.1 \\
\hline \multicolumn{3}{|l|}{ Marital status } \\
\hline Married & 752 & 75.2 \\
\hline Single & 205 & 20.5 \\
\hline Divorced & 43 & 4.3 \\
\hline \multicolumn{3}{|l|}{ Educational level } \\
\hline Literacy & 4 & 0.4 \\
\hline Primary school (5 years) & 57 & 5.7 \\
\hline Primary school (8 years) & 46 & 4.6 \\
\hline High School & 212 & 21.2 \\
\hline Vocational School & 96 & 9.6 \\
\hline Bachelor's Degree & 463 & 46.3 \\
\hline Post Degree (master and Ph.D) & 122 & 12.2 \\
\hline \multicolumn{3}{|l|}{ Number of family members } \\
\hline 1 & 83 & 8.3 \\
\hline 2 & 183 & 18.3 \\
\hline 3 & 275 & 27.5 \\
\hline 4 & 319 & 31.9 \\
\hline More than 4 & 140 & 14.0 \\
\hline
\end{tabular}


Table 2. Demographic...

\begin{tabular}{|c|c|c|}
\hline & Frequency (n) & Percent (\%) \\
\hline \multicolumn{3}{|c|}{ Number of revenue generating family members } \\
\hline 1 & 437 & 43.7 \\
\hline 2 & 495 & 49.5 \\
\hline 3 & 50 & 5.0 \\
\hline 4 & 15 & 1.5 \\
\hline More than 4 & 3 & 0.3 \\
\hline \multicolumn{3}{|l|}{ Income } \\
\hline No & 160 & 16.0 \\
\hline Less than $1.603 \mathrm{TL}$ & 52 & 5.2 \\
\hline $1.604 \mathrm{TL}-2.600 \mathrm{TL}$ & 139 & 13.9 \\
\hline $2.601 \mathrm{TL}-3.600 \mathrm{TL}$ & 150 & 15.0 \\
\hline 3.601 TL- $4.600 \mathrm{TL}$ & 129 & 12.9 \\
\hline $4601 \mathrm{TL}-5.600 \mathrm{TL}$ & 108 & 10.8 \\
\hline More than $5.601 \mathrm{TL}$ & 262 & 26.2 \\
\hline \multicolumn{3}{|l|}{ Household's Income } \\
\hline Less than $1.603 \mathrm{TL}$ & 24 & 2.4 \\
\hline 1604 TL-2600 TL & 73 & 7.3 \\
\hline 2601 TL- 3600 TL & 112 & 11.2 \\
\hline 3601 TL- $4600 \mathrm{TL}$ & 121 & 12.1 \\
\hline 4601 TL- $5600 \mathrm{TL}$ & 118 & 11.8 \\
\hline $5601 \mathrm{TL}$ and over & 552 & 55.2 \\
\hline \multicolumn{3}{|c|}{ Who is the decision maker about financial action? } \\
\hline You & 383 & 38.3 \\
\hline You and your wife & 456 & 45.6 \\
\hline Wife & 46 & 4.6 \\
\hline You and other family members & 115 & 11.5 \\
\hline
\end{tabular}


Table 2. Demographic...

\begin{tabular}{|l|c|c|}
\hline \hline & Frequency (n) & Percent (\%) \\
\hline \hline \multicolumn{2}{|c|}{ Working status } \\
\hline Non-worker & 251 & 25.1 \\
\hline Worker & 749 & 74.9 \\
\hline \hline
\end{tabular}

S o u r c e : compiled by the author.

$30.6 \%$ of the participants in the study are women and $69.4 \%$ are men. $3.3 \%$ of participants between 18-24, 24.3\% between $25-34,33.5 \%$ between $35-44$, $24.7 \%$ between $45-54,10.1 \%$ between $55-64,4.1 \%$ has 65 and over age. $75.2 \%$ of the participants are married, $20.5 \%$ are single and $4.3 \%$ are divorced. While $0.4 \%$ of the participants are literate; $5.7 \%$ have 5 -year primary school, $4.6 \%$ 8-year primary school, $21.2 \%$ high school, $9.6 \%$ associate degree, $46.3 \%$ undergraduate and $12.2 \%$ graduate education. $8.3 \%$ of the participants have one other than their own, $18.3 \%$ two, $27.5 \%$ three, $31.9 \%$ four, $14.0 \%$ over 4 family members. $5.2 \%$ of the participants are below $1603 \mathrm{TL}, 13.9 \%$ between 1604-2600 TL, $15.0 \%$ between $2601-3600$ TL, $12.9 \%$ between $3601-4600$ TL, $10.8 \%$ between $4601-5600$ TL $26.2 \%$ of them have 5601 TL and above income. $2.4 \%$ of the participants are below $1603 \mathrm{TL}, 7.3 \%$ between 1604-2600 TL, $11.2 \%$ between $2601-3600 \mathrm{TL}, 12.2 \%$ between $3601-4600 \mathrm{TL}, 11.8 \%$ between 4601-5600 TL 55.2\% of them have family income of TL 5601 and above. While $38.3 \%$ of the participants made financial decisions themselves, $45.6 \%$ of them stated that they made them with their spouses, $4.6 \%$ of them made their spouses and $11.5 \%$ of them agreed with the family. $74.9 \%$ of the participants stated that while working $25.1 \%$ stated that they were not working.

Correlation matrix of study variables is given in the table 3. 
Table 3. Correlation matrix of study variables (Spearman's rho Test)

\begin{tabular}{|l|c|c|c|c|c|c|c|}
\hline \hline & Age & $\begin{array}{c}\text { Marital } \\
\text { status }\end{array}$ & Education & $\begin{array}{c}\text { N. of family } \\
\text { members }\end{array}$ & $\begin{array}{c}\text { N. of income } \\
\text { person }\end{array}$ & Income & $\begin{array}{c}\text { House } \\
\text { income }\end{array}$ \\
\hline \hline Marital status & $-0.150^{* *}$ & & & & & \\
\hline Education & $-0.097^{* *}$ & 0.006 & & & & & \\
\hline $\begin{array}{l}\text { N. of family } \\
\text { members }\end{array}$ & 0.001 & $-0.402^{* *}$ & $-0.199^{* *}$ & & & & \\
\hline $\begin{array}{l}\text { N. of income } \\
\text { person }\end{array}$ & -0.029 & -0.057 & $0.152^{* *}$ & $0.229^{* *}$ & & & \\
\hline Income & 0.043 & -0.047 & $0.274^{* *}$ & -0.043 & 0.028 & & \\
\hline House income & -0.050 & $-0.122^{* *}$ & $0.347^{* *}$ & $0.086^{* *}$ & $0.303^{* *}$ & $0.436^{* *}$ & \\
\hline Working & $-0.393^{* *}$ & -0.008 & $0.233^{* *}$ & 0.041 & $0.153^{* *}$ & $0.402^{* *}$ & $0.288^{* *}$ \\
\hline \hline
\end{tabular}

$* * \mathrm{p}<0.01$

S o u r c e : compiled by the author.

There is a statistically significant and negative relationship between the participants' ages and marital status, education and employment status $(\mathrm{p}<0.01)$. There is a negative relationship between marital status and number of family members and household income $(\mathrm{p}<0.01)$. There is a positive relationship between the number of individuals in the family and the income generating family and household income $(\mathrm{p}<0.01)$. There is a positive relationship between the number of income earners and household income and working status $(\mathrm{p}<0.01)$. There is a positive relationship between income and household income and working status $(\mathrm{p}<0.01)$. There is a positive relationship between household income and working status ( $\mathrm{p}<0.01)$. Contingency results explaining financial literacy and explanatory variables are given in the table 4 .

Table 4. Contingency tables - financial literacy x explanatory variables

\begin{tabular}{|c|c|c|c|c|c|c|}
\hline & \multicolumn{2}{|c|}{ Low ( $n=471 ; \% 47.1)$} & \multicolumn{2}{|c|}{ High ( $n=529 ; \% 52.9$ ) } & \multirow{2}{*}{$x^{2}$} & \multirow{2}{*}{$\mathbf{p}$} \\
\hline & f & $\%$ & f & $\%$ & & \\
\hline \multicolumn{7}{|l|}{ Gender } \\
\hline Female & 177 & 57.8 & 129 & 42.2 & 20.424 & 0.000 \\
\hline Male & 294 & 42.4 & 400 & 57.6 & & \\
\hline
\end{tabular}


11. THE DETERMINANTS OF the LEVEL OF FINANCIAL LITERACy IN TURKEY

Table 4. Contingency...

\begin{tabular}{|c|c|c|c|c|c|c|}
\hline & \multicolumn{2}{|c|}{ Low $(n=471 ; \% 47.1)$} & \multicolumn{2}{|c|}{ High ( $n=529 ; \% 52.9$ ) } & \multirow{2}{*}{$x^{2}$} & \multirow{2}{*}{$\mathbf{p}$} \\
\hline & f & $\%$ & $f$ & $\%$ & & \\
\hline \multicolumn{7}{|l|}{ Age } \\
\hline $18-24$ & 26 & 78.8 & 7 & 21.2 & & \\
\hline $25-34$ & 131 & 53.9 & 112 & 46.1 & & \\
\hline $35-44$ & 153 & 45.7 & 182 & 54.3 & 26.900 & 0.000 \\
\hline $45-54$ & 110 & 44.5 & 137 & 55.5 & & \\
\hline $55-64$ & 39 & 38.6 & 62 & 61.4 & & \\
\hline $65+$ & 12 & 29.3 & 29 & 70.7 & & \\
\hline \multicolumn{7}{|l|}{ Marital status } \\
\hline Married & 334 & 44.4 & 418 & 55.6 & & \\
\hline Single & 115 & 56.1 & 90 & 43.9 & 9.122 & 0.010 \\
\hline Divorced & 22 & 51.2 & 21 & 48.8 & & \\
\hline \multicolumn{7}{|l|}{ Educational level } \\
\hline Literacy & 3 & 75.0 & 1 & 25.0 & & \\
\hline Primary school (5 years) & 38 & 66.7 & 19 & 33.3 & & \\
\hline Primary school (8 years) & 28 & 60.9 & 18 & 39.1 & 26.312 & 0.000 \\
\hline High School & 116 & 54.7 & 96 & 45.3 & & \\
\hline Vocational School & 44 & 45.8 & 52 & 54.2 & & \\
\hline Bachelor's Degree & 193 & 41.7 & 270 & 58.3 & & \\
\hline Post Degree (master and Ph.D) & 49 & 40.2 & 73 & 59.8 & & \\
\hline \multicolumn{7}{|l|}{ Number of family members } \\
\hline 1 & 42 & 50.6 & 41 & 49.4 & & \\
\hline 2 & 89 & 48.6 & 94 & 51.4 & 2.678 & 0.613 \\
\hline 3 & 131 & 47.6 & 144 & 52.4 & & \\
\hline 4 & 139 & 43.6 & 180 & 56.4 & & \\
\hline More than 4 & 70 & 50.0 & 70 & 50.0 & & \\
\hline \multicolumn{7}{|c|}{ Number of revenue generating family members } \\
\hline 1 & 211 & 48.3 & 226 & 51.7 & & \\
\hline
\end{tabular}


Table 4. Contingency...

\begin{tabular}{|c|c|c|c|c|c|c|}
\hline & \multicolumn{2}{|c|}{ Low $(n=471 ; \% 47.1)$} & \multicolumn{2}{|c|}{ High ( $n=529 ; \% 52.9)$} & \multirow{2}{*}{$x^{2}$} & \multirow{2}{*}{ p } \\
\hline & f & $\%$ & f & $\%$ & & \\
\hline 2 & 233 & 47.1 & 262 & 52.9 & 3.181 & 0.528 \\
\hline 3 & 18 & 36.0 & 32 & 64.0 & & \\
\hline 4 & 7 & 46.7 & 8 & 53.3 & & \\
\hline More than 4 & 2 & 66.7 & 1 & 33.3 & & \\
\hline \multicolumn{7}{|l|}{ Income } \\
\hline No & 87 & 54.4 & 73 & 45.6 & & \\
\hline Less than1603 TL & 28 & 53.8 & 24 & 46.2 & & \\
\hline 1604 TL-2600 TL & 75 & 54.0 & 64 & 46.0 & 11.146 & 0.084 \\
\hline 2601 TL- 3600 TL & 65 & 43.3 & 85 & 56.7 & & \\
\hline 3601 TL- 4600 TL & 57 & 44.2 & 72 & 55.8 & & \\
\hline 4601 TL- 5600 TL & 49 & 45.4 & 59 & 54.6 & & \\
\hline More than $5601 \mathrm{TL}$ & 110 & 42.0 & 152 & 58.0 & & \\
\hline \multicolumn{7}{|l|}{ Household's Income } \\
\hline Less than $1603 \mathrm{TL}$ & 9 & 37.5 & 15 & 62.5 & & \\
\hline 1604 TL-2600 TL & 39 & 53.4 & 34 & 46.6 & & \\
\hline 2601 TL- 3600 TL & 59 & 52.7 & 53 & 47.3 & 4.253 & 0.514 \\
\hline 3601 TL- 4600 TL & 57 & 47.1 & 64 & 52.9 & & \\
\hline 4601 TL- 5600 TL & 57 & 48.3 & 61 & 51.7 & & \\
\hline $5601 \mathrm{TL}$ and over & 250 & 45.3 & 302 & 54.7 & & \\
\hline \multicolumn{7}{|c|}{ Who is the decision maker about financial action? } \\
\hline You & 176 & 46.0 & 207 & 54.0 & & \\
\hline You and your wife & 202 & 44.3 & 254 & 55.7 & 9.010 & 0.029 \\
\hline Wife & 27 & 58.7 & 19 & 41.3 & & \\
\hline You and other family members & 66 & 57.4 & 49 & 42.6 & & \\
\hline \multicolumn{7}{|l|}{ Working status } \\
\hline Non-worker & 114 & 45.4 & 137 & 54.6 & 0.380 & 0.537 \\
\hline Worker & 357 & 47.7 & 392 & 52.3 & & \\
\hline
\end{tabular}

S o u r c e : compiled by the author. 
$57.8 \%$ of women and $42.4 \%$ of men have low financial literacy knowledge, this difference is statistically significant ( $\mathrm{p}<0.05$ ). $78.8 \%$ of those aged $18-24$, $53.9 \%$ of those aged $25-34,45.7 \%$ of those aged $35-44,44.5 \%$ of those aged $45-54,55-38.6 \%$ of those aged between 64 and $29.3 \%$ of those aged over 65 have financial literacy knowledge, this difference is statistically significant ( $\mathrm{p}<0.05$ ). $44.4 \%$ of married participants, $56.1 \%$ of single participants, $51.2 \%$ of divorced participants have low financial literacy knowledge and these differences are statistically significant ( $\mathrm{p}<0.05$ ). $75.0 \%$ of literate people, $66.7 \%$ of 5-year primary school graduates, $60.9 \%$ of 8 -year primary school graduates, $54.7 \%$ of high school graduates, $45.8 \%$ of associate degree graduates, $41.7 \%$ of graduate graduates, graduate graduates 40.2 of them have financial literacy knowledge and this difference is statistically significant ( $p<0.05$ ). $50.6 \%$ of those who have a person outside their family, $48.6 \%$ of those who are two, $47.6 \%$ of those who are three, $43.6 \%$ of those who are four, $50.0 \%$ of those who are more than four individuals have lower financial literacy knowledge, however, these differences are not statistically significant ( $p>0.05$ ). $48.3 \%$ of those who have income from their own family, $47.1 \%$ of those who are two, $36.0 \%$ of those who are three, $46.7 \%$ of those who are four, $66.7 \%$ of those who are more than four individuals have lower financial literacy knowledge, but these differences are not statistically significant ( $p>0.05) .53 .8 \%$ of those with a monthly income of $1603 \mathrm{TL}$ and below, $54.0 \%$ of those between 1604-2600 TL, 43.3\% of those with 2601-3600 TL, 44.2\% of those between 3601-4600 TL, those between 4601-5600 TL 45.4\%, 42.0\% of those with TL 5601 and above have low financial literacy knowledge and this difference is not statistically significant ( $p>0.05$ ). 37.5\% of households with household income of 1603 TL and below, $53.4 \%$ of those between $1604-2600 \mathrm{TL}, 52.7 \%$ of those with $2601-3600 \mathrm{TL}$, $47.1 \%$ of those between $3601-4600 \mathrm{TL}, 4601-5600 \mathrm{TL} 48.3 \%$ of the ones, $45.3 \%$ of those with TL 5601 and above have low financial literacy knowledge and this difference is not statistically significant ( $p>0.05$ ). $46.0 \%$ of those who make the decisions themselves in the family, $44.3 \%$ of themselves and their spouses, $58.7 \%$ of the spouses and $57.4 \%$ of family members have low financial literacy level and this difference is statistically significant ( $\mathrm{p}<0.05$ ). $45.4 \%$ of those who do not work and $47.7 \%$ of employees have low financial literacy level and these differences are not statistically significant ( $p>0.05$ ).

Logit nonlinear results for research parameters and financial literacy are given in the table 5 . 
Table 5. Logit nonlinear result for research parameters and financial literacy

\begin{tabular}{|c|c|c|c|c|}
\hline & \multicolumn{4}{|c|}{ Logit } \\
\hline & \multicolumn{2}{|c|}{ Model } & \multicolumn{2}{|c|}{ Marginal effects } \\
\hline & Coefficient & p & Coefficient & p \\
\hline Gender & 0.646 & $0.000 *$ & 0.149 & $0.000^{*}$ \\
\hline Age & 0.241 & $0.000 *$ & 0.055 & $0.000 *$ \\
\hline Marital status & -0.150 & 0.270 & -0.034 & 0.269 \\
\hline Living family mem. & 0.067 & 0.313 & 0.015 & 0.312 \\
\hline Education & 0.297 & $0.000 *$ & 0.068 & $0.000 *$ \\
\hline Income & 0.044 & 0.256 & 0.010 & 0.255 \\
\hline N. of income person & 0.028 & 0.798 & 0.006 & 0.798 \\
\hline House income & -0.060 & 0.153 & -0.014 & 0.152 \\
\hline Working & -0.335 & 0.094 & -0.077 & 0.092 \\
\hline Constant & -2.989 & $0.000^{*}$ & & \\
\hline$x 2$ & 78.38 & & & \\
\hline$x 2 p$ & 0.000 & & & \\
\hline $\mathrm{R} 2$ & 0.057 & & & \\
\hline Log likelihood & -652.274 & & & \\
\hline Observation & 1000 & & & \\
\hline
\end{tabular}

S o u r c e : compiled by the author.

In the logit model, the contribution of gender, age and education on the level of financial literacy is statistically significant $(\mathrm{p}<0.05)$. The marginal effect results are also compatible with the results obtained in the logit model. In the logit model, the effect of gender, age and education was positive. Since the ranking for gender is coded as female-male, the level of financial literacy increases when gender passes from female to male. This situation is also seen in Table 4. Since age and education parameters are coded increasingly, financial literacy level increases with age and education. The explanatory power of the model is 0.057 , and the model is significant in predicting the relationship between financial literacy and demographic characteristics $\left(\mathrm{X}^{2}: 78.38 ; \mathrm{p}<0.01\right)$. Moreover, in 
the model, the hypotheses $\mathrm{H}_{1}, \mathrm{H}_{2}$ and $\mathrm{H}_{5}$ were accepted, whereas the hypotheses $\mathrm{H}_{3}, \mathrm{H}_{4}, \mathrm{H}_{6}, \mathrm{H}_{7}, \mathrm{H}_{8}$ and $\mathrm{H}_{9}$ were rejected. Considering the results on the hypotheses in detail, in their studies, Chen and Volpe (1998), Lusardi and Mitchell (2007), Agarwal, Driscoll, Gabaix and Laibson (2009), Lusardi and Mitchell (2011), Atkinson and Messy (2012), OECD (2013), Brown and Graf (2013), Mahdzan and Victorian (2013) and Potrich et al. (2015) accepted the hypothesis " $H_{1}$ : Gender has a statistically significant predictive effect on level of financial literacy." They explained the effect of gender on financial literacy as that women are financially less literate than men. This situation supported the results on the hypothesis in this study. Additionally, Agarwal et al. (2009), Lusardi and Mitchell (2011), Atkinson and Messy (2012), OECD (2013) and Scheresberg (2013) accepted the hypothesis " $\mathrm{H}_{2}$ : Age has a statistically significant predictive effect on level of financial literacy." This situation showed that younger individuals are less financially literate than older individuals, and as age increases, people are more likely to become more financially literate. In addition to this, the increased experiences of individuals who are older makes a positive contribution to the increase in their financial literacy levels. This study also supported this hypothesis, but Potrich et al. (2015) rejected it. Research (2003), Calamato (2010) and Brown and Graf (2013) obtained results supportive of the hypothesis " $H_{3}$ : Marital status has a statistically significant predictive effect on level of financial literacy." This was stated in their studies as single individuals are less financially literate than married individuals. The results obtained by this study and the study by Potrich et al. (2015) were similar, and they rejected the hypothesis $\mathrm{H}_{3}$. Servon and Kaestner (2008) and Mottola (2013) obtained results supportive of the hypothesis " $\mathrm{H}_{4}$ : Number of family members has a statistically significant predictive effect on level of financial literacy." They argued that, as the number of individuals living in a household increases, the financial literacy level is lower. However, in this study, they hypothesis $\mathrm{H}_{4}$ was rejected. Furthermore, Chen and Volpe (1998), Hogarth (2002), Lusardi and Mitchell (2011) and Mahdzan and Victorian (2013) obtained results that supported the hypothesis " $H_{5}$ : Education has a statistically significant predictive effect on level of financial literacy." It was determined that individuals who have undergraduate and postgraduate degrees are more financially literate than those with high school or primary school degrees. This finding was similar to those in this study. Monticone (2010), Hastings and Mitchell (2011) and Atkinson and Messy (2012) found results that supported the hypotheses " $H_{6}$ : Income has a statistically significant predictive effect on level of financial literacy" and " $H_{7}$ : Number of persons 
with income has a statistically significant predictive effect on level of financial literacy." It was observed that individuals with lower income have lower financial literacy levels. On the other hand, this study and the study by Potrich et al. (2015) did not obtain results that supported the aforementioned hypotheses and the hypothesis " $H_{8}$ : Household income has a statistically significant predictive effect on level of financial literacy." Chen and Volpe (1998), Research (2003), Kim and Garman (2004) and Calamato (2010) obtained results supportive of the hypothesis " $\mathrm{H}_{9}$ : Working condition has a statistically significant predictive effect on level of financial literacy," but neither this study nor the study by Potrich et al. (2015) could find a statistically significant relationship.

\section{CONCLUSIONS AND RECOMMENDATION}

The purpose of this study was to explain the significance and components of financial literacy for the purpose of increasing the financial literacy levels of financial consumers. In the scope of the study, the relationship between the financial literacy levels and sociodemographic characteristics of individuals living in the LEVEL 1 region of Turkey was investigated. As a result, a significant and positive relationship was determined between financial literacy and the variables of gender, age and educational status. Accordingly, men were found to have higher financial literacy levels then women. It was additionally determined that the financial literacy levels of individuals with postgraduate degrees were higher, while the financial literacy levels of individuals at the ages of 18-24 were lower. In this study, among the participants of the questionnaire, the financial literacy levels of $52.9 \%$ were high, while those of $47.1 \%$ were low. This situation reveals the necessity of conducting work to increase the financial knowledge and financial literacy levels in Turkey. This way, in societies whose financial literacy levels increase, responsible saving tendencies will increase. It is considered that, as a result of this, increased investments will create a significant effect on growth. Realizing this situation is a long-term process. What needs to be done in this process may be to establish and infrastructure. For example, such an infrastructure may include offering courses containing basic finance knowledge at educational institutions on the level of high schools, including compulsory financial literacy courses in the first year curricula of all departments regardless of field and constantly keeping this issue in the agenda on the print and visual media. In the case that such efforts are made, not only 
will the financial literacy levels in Turkey start to rise in the medium run, but a healthier responsibility of saving will also start to develop. In a longer term, several positive effects of this on Turkey's economy will be observe.

\section{ACKNOWLEDGEMENTS}

This study which is SBA-2018-10112 number was supported by Scientific Research Projects -Cukurova University.

\section{REFERENCES}

Agarwal, S., Driscoll, J., Gabaix, X., \& Laibson, D. (2009). The Age of Reason: Financial Decisions over the Lifecycle with Implications for Regulation. Brookings Papers on Economic Activity, 2, 51-117.

Alkaya, A., \& Yağlı, İ. (2015). Finansal Okuryazarlık-Finansal Bilgi, Davranış ve Tutum: Nevşehir Hacı Bektaş Veli Üniversitesi İ̉BF Öğrencileri Üzerine Bir Uygulama. Journal of International Social Research, 8(40), 585-585. http://dx.doi.org/10.17719/ jisr.20154013941.

Ansong, A., \& Gyensare, M.A. (2012). Determinants of University Working-students' Financial Literacy at the University of Cape Coast, Ghana. International Journal of Business and Management, 7(9), 126-133. http://dx.doi.org/10.5539/ijbm.v7n9p126.

Atkinson, A., \& Messy, F. (2012). Measuring Financial Literacy: Results of the OECD / International Network on Financial Education (INFE) Pilot Study. OECD Working Paper, 15. http://dx.doi.org/10.1787/5k9csfs90fr4-en.

Bağcl, H., \& Arabacı, S.M. (2019). Finansal Okuryazarlık Düzeyinin ve Finansal Okuryazarlığı Etkileyen Faktörlerin Belirlenmesi. Business \& Management Studies: An International Journal, 7(3), 68-88. http://dx.doi.org/10.15295/bmij.v7i3.1232.

Bayram, S.S. (2014). Finansal Okuryazarlık ve Para Yönetimi Davranışları: Anadolu Üniversitesi Öğrencileri Üzerine Uygulama. Business \& Management Studies: An International Journal, 2(2), 105-135. http://dx.doi.org/10.15295/bmij.v2i2.68.

Boz, D. (2019). Kütahya İlinde Bulunan Özel Eğitim Kurumlarında Öğrenim Gören Öğrenci Velilerinin Finansal Okuryazarlık Düzeylerinin Belirlenmesi. Muhasebe ve Finansman Dergisi, 82, 147-160.

Brown, M., \& Graf, R. (2013). Financial literacy and retirement planning in Switzerland. Numeracy, 6(2), 1-21.

Calamato, M.P. (2010). Learning Financial Literacy in the Family. Unpublished master's thesis. The Faculty of the Department of Sociology, San José State University.

Çam, A.V., \& Barut, A. (2015). Finansal Okuryazarlık Düzeyi ve Davranışları: Gümüşhane Üniversitesi Önlisans Öğrencileri Üzerinde Bir Araștırma. Global Journal of Economics and Business Studies, 4(7), 63-72. 
Çam, H., Ayaydın, H., Çam, A.V., \& Akdeniz, F. (2018). Bireylerin Finansal Bilgi Düzeyi ile Finansal Katılım Düzeyi Arasındaki İlişki: TR 90 Bölgesinde Bir Araștırma. Ekonomi Bilimleri Dergisi, 10(1), 1-13.

Çelikkol, M.M., \& Çelikkol, H. (2015). The evaluation of the students in Dumlupinar University Vocational School of Social sciences about levels of financial literacy. Copernican Journal of Finance \& Accounting, 4(2), 43-63. http://dx.doi.org/10.12775/ CJFA.2015.015.

Chen, H., \& Volpe, R.P. (1998). An Analysis of Personal Financial Literacy among College Students. Financial services review, 7(2), 107-128.

Cude, B., Lawrence, F., Lyons, A., Metzger, K., LeJeune, E., Marks, L., \& Machtmes, K. (2006). College Students and Financial Literacy: What They Know and What We Need to Learn. Proceedings of the Eastern Family Economics and Resource Management Association, 102(9), 106-109.

Danes, S.M., \& Hira, T.K. (1987). Money Management Knowledge of College Students. Journal of Student Financial Aid, 17(1), 4-16.

Danışman, E., Sezer, D., \& Gümüş, U.T. (2016). Finansal Okuryazarlık Düzeyinin Belirlenmesi: Üniversite Öğrencileri Üzerine Bir Araştırma. Kara Harp Okulu Bilim Dergisi, 26(2), 1-37.

Dilek, S., Küçük, O., \& Eleren, A. (2016). Kastamonu Üniversitesi Öğrencilerinin Ekonomi Okuryazarlığı. Insan ve Toplum Bilimleri Araştırmaları Dergisi, 5(7), 1865-1878. http://dx.doi.org/10.15869/itobiad.259311.

Er, F., Temizel, F., Özdemir, A., \& Sönmez, H. (2014). Lisans Eğitim Programlarının Finansal Okuryazarlık Düzeyine Etkisinin Araștırılması: Türkiye Örneği. Anadolu Üniversitesi Sosyal Bilimler Dergisi, 14(4), 113-125.

Ergün, B., Şahin, A., \& Ergin, E. (2014). Finansal Okuryazarlık: İşletme Bölümü Öğrencileri Üzerine Bir Çalışma. Journal of International Social Research, 7(34), 847- 864.

FODER (2020). FODER Hakkında, https://www.fo-der.org/foder-hakkinda (accessed: 15.04.2019).

FODER (2020). FODER ve Visa, Türkiye'nin Finansal Okuryazarlık Haritasını Çıkardı, https://www.fo-der.org/foder-ve-visa-turkiyenin-finansal-okuryazarlik-haritasini-cikardi (accessed: 7.05.2019).

Furtuna, F. (2007). College Students' Personal Financial Literacy: Economic Impact and Public Policy Implications. Undergraduate Economic Review, 4(1), 1-32.

Gökmen, H. (2012). Finansal Okuryazarlık. Baskı İstanbul: Hiperlink Yayınları.

Hastings, J., \& Mitchell, O.S. (2011). Financial Literacy: Implications for Retirement Security and the Financial Marketplace. Oxford, UK: Oxford University Press.

Hogarth, J.M. (2002). Financial Literacy and Family and Consumer Sciences. Journal of Family and Consumer Sciences, 94(1), 15-28.

Karabacak, S. (2013). Yönetim Kurumları ve Finansal Okuryazarlık. Anadolu Üniversitesi Sosyal Bilimler Dergisi, 15(3), 1-7. http://dx.doi.org/10.18037/ausbd.25871.

Kieschnick, D.A.H. (2006). Financial knowledge levels and savings behaviors of Bermudian high school seniors at CedarBridge Academy. Retrospective Theses and Dissertations, 864. http://dx.doi.org/10.31274/rtd-180813-9896. 
Kim, J., \& Garman, E.T. (2004). Financial Stress, Pay Satisfaction and Workplace Performance. Compensation Benefits Review, 36(1), 69-76. http://dx.doi. org/10.1177/0886368703261215.

Lusardi, A., \& Mitchell, O.S. (2007). Financial Literacy and Planning: Implications for Retirement Wellbeing. Wharton Pension Research Council Working Papers, 211.

Lusardi, A., \& Mitchell, O.S. (2011). Financial Literacy and Retirement Planning in the United States. Journal of Pension Economics and Finance, 10(4), 509-525. https:// dx.doi.org/10.1017/S147474721100045X.

Lusardi, A., Mitchell, O.S., \& Curto, V. (2010). Financial Literacy among the Young. Journal of consumer affairs, 44(2), 358-380. http://dx.doi.org/10.1111/j.1745-6606.2010.01173.x.

Mahdzan, N.S., \& Victorian, S.M.P. (2013). The Determinants of Life Insurance Demand: A Focus on Saving Motives and Financial Literacy. Asian social science, 9(5), 274. http://dx.doi.org/10.5539/ass.v9n5p274.

Mason, C.L.J., \& Wilson, R.M.S. (2000). Conceptualising fi-financial literacy. Occasional paper, 7.

Monticone, C. (2010). How Much Does Wealth Matter in the Acquisition of Financial Literacy? The Journal of Consumer Affairs, 44(2), 403-422. http://dx.doi.org/10.1111/ j.1745-6606.2010.01175.x.

Mottola, G.R. (2013). In Our Best Interest: Women, Financial Literacy, and Credit Card Behavior. Numeracy, 6(2), 1-15. http://dx.doi.org/10.5038/1936-4660.6.2.4.

OECD (2005). Improving Financial Literacy Analysis of Issues and Policies Organization, https://www.oecd.org/finance/financial education/improvingfinanciallitera cvanalvsisofissuesandpolicies.html (accessed: 12.10.2019).

OECD (2013). Financial Literacy and Inclusion: Results of OECD/INFE Survey across Countries and by Gender. Paris, France: OECD Publishing.

Orton, L. (2007). Financial Literacy: Lessons from International Experience. Canadian Policy Research Networks, Incorporated.

Potrich, A.C.G., Vieira, K.M., \& Kirch, G. (2015). Determinants of Financial Literacy: Analysis of the Influence of Socioeconomic and Demographic Variables. Revista Contabilidade \& Finanças, 26(69), 362-377. http://dx.doi.org/10.1590/1808-057x201501040.

Research, R.M. (2003). Survey of Adult Financial Literacy in Australia. ANZ Banking Group. https://www.anz.com/australia/support/library/MediaRelease/MR20030502a.pdf.

Schagen, S., \& Lines, A. (1996). Financial Literacy in Adult Life: A Report to the Natwest Group Charitable Trust. NFER, 36-45.

Scheresberg, C.B. (2013). Financial Literacy and Financial Behavior among Young Adults: Evidence and Implications. Numeracy, 6(2), 1-21. http://dx.doi.org/10.5038/19364660.6.2.5.

Servon, L.J., \& Kaestner, R. (2008). Consumer Financial Literacy and the Impact of Online Banking on the Financial Behavior of Lower-income Bank Customers. Journal of Consumer Affairs, 42(2), 271-305. http://dx.doi.org/10.1111/j.1745-6606.2008.00108.x.

Taşçı, M. (2011). Okullarda Temel Finans Eğitimi Verilmesinin Önemi, Dünya Uygulamaları, Öneriler. Sermaye Piyasası Dergisi, 5, 87-103. 
Van Rooij, M., Lusardi, A., \& Alessie, R. (2011). Financial Literacy and Stock Market Participation. Journal of Financial Economics, 101(2), 449-472. http://dx.doi. org/10.1016/j.jfineco.2011.03.006.

Volpe, R.P., Chen, H., \& Pavlicko, J.J. (1996). Personal Investment Literacy among College Students: A survey. Financial Practice and Education, 6(2), 86-94.

Worthington, A.C. (2006). Predicting Financial Literacy in Australia. Financial Services Review, 15(1), 59-79. 